\title{
IAMJ
}

INTERNATIONAL

AYURVEDIC

MEDICAL JOURNAL

\section{APPLIED STUDY OF SAMANYA VISHESH SIDDHANTA IN TREATMENT OF AMLAPITTA (HYPERACIDITY)}

\author{
Kankre Rameshwari ${ }^{1}$, Sajjanshethy M.R ${ }^{2}$, Kanolli G.N ${ }^{3}$ \\ ${ }^{1}$ P.G. Scholar, Department of Samhita Siddhanta, S.V.M Ayurvedic Medical College and Hospital, \\ Ilkal, Karnataka, India \\ ${ }^{2}$ Professor, Dept. of Samhita Siddhanta, S.V.M Ayurveda Medical College, Ilkal, Karnataka, India \\ ${ }^{3}$ Lecturer, Dept. of Samhita Siddhanta, S.V.M Ayurveda Medical College, Ilkal, Karnataka, India
}

Corresponding Author: vishwaradhe99@gmail.com

\section{https://doi.org/10.46607/iamj3509102021}

(Published Online: October 2021)

Open Access

(C) International Ayurvedic Medical Journal, India 2021

Article Received: 28/09//2021 - Peer Reviewed: 07/10/2021 - Accepted for Publication: 08/10/2021

\section{Check for updates}

\section{ABSTRACT}

Background: Ayurveda is comprehensive science that prizes the information on every single detail to carry on with a sound, rich and glad life. This fortune is its essential standard. Each infection happens because of aggravation in the condition of balance condition of the body's dosha, dhatu or mala i.e. either increment or abatement in their state. Fundamental standards of this science resemble profound foundations of the tree which will in every case firmly hold the gigantic tree of Ayurveda. Samanya Vishesh Siddhanta is the essential and most normal guideline for the treatment of any sickness in Ayurveda. Samanya implies comparability or consistency and Vishesh indicates dissimilarity or nonuniformity. Amplapitta (hyperacidity) happens because of the insanity of Agni in this manner changing the business as usual of pitta dosha. The state of Amlapitta is one of them. This can be treated by the fundamental guideline of Samanya Vishesh Siddhanta. Because of modifications in food and way of life many individuals are succumbing to stomach related issues. The present article includes guidelines and significance of Samaya Vishesh Siddhant in treating the state of Amlapitta. Objective: To concentrate on the rule of Samanya Vishesh Siddhant exhaustively and its application in forestalling and treating the state of Amlapitta. Methods: Study material was acquired from traditional texts, bona fide diaries, and articles. A different idea of 
this subject is additionally talked about to make an inference. Conclusion: Samanya Vishesh Siddhanta is an essential guideline in the treatment of any sickness. State of Amlapitta cannot exclusively be dealt with yet, in addition, be kept from repeat utilizing this heavenly standard laid by our Acharyas.

Keywords: Siddhanta, Dosha, Dhatu, Mala.

\section{INTRODUCTION}

Ayurveda is all-encompassing science that gives information on life. ${ }^{1}$ Its advantage is wellbeing by providing factors liable for its upkeep and advancement. The primary thought process of Ayurveda is the support of strength of solid people and treating the ailing one. ${ }^{2}$ When there is harmony in the condition of doshas, dhatus and mama las sound state is achieved. ${ }^{3}$ Ayurveda is showering its significant fortune to humankind for quite a while in the past. A tree can't stand and live without its root, comparatively the study of Ayurveda isn't anything without its Siddhantas. There are different Siddhantas clarified in Ayurveda Dosha dhatu mala Siddhanta, panchmahabhut Siddhant, triguna Siddhant, Ojh, Shad padartha, AtmaPunarjanma, Moksha, Lok-Purusha Samya, Samanya Vishesha and so on However these siddhantas were laid long years prior by our acharyas, still, in 21 st century their significance and appropriateness are same. These siddhantas will be similarly productive in the forthcoming period for research work to serve humankind for the advancement of wellbeing and treatment of dis simplicity. Among every one of these Samanya Vishesh Sid-dhanta has its own significance in each period of life. This rule of likeness and dissimilarity helps in the fulfilment of a condition of equilibrium among dosha, dhatu and mala of body.

Change in food propensities and way of life drives a number of issues. Dyspepsia, hyperacidity, peptic ulcer infection is a portion of the common sufferings seen because of unfortunate eating routine and illadvised time, stress, overexertion, absence of rest. It is assessed that $23-33 \%$ of the Indian populace is experiencing gastritis. ${ }^{4}$ The un-acclimated variety in same straightforwardly or indirectly influences assimilation prompting agnimandya or exhausted stomach related system and in this manner ajirna is creat- ed. This prompts the arrangement of amavisha-a substance other than regular digestive parts hurtful for the body. This sub-position then, at that point, blended in with dosha particularly pitta dosha and collected in amashaya gradually coming about to state of Amlapitta. ${ }^{5}$ Amlapitta is a condition where pachak pitta dosha gets mutilated in an uncommon way alongside vitiation of kledak kapha and saman vaayu. Madhav ni-daan has referenced the clinical situation of Amlapitta. Presence of avipaka

- indigestion, klama

- tiredness, utklesha

- nausea, amlodgara, Gaurav

- heaviness in the body, hrit-kantha daha

- burning sensation in throat, heart, and abdomen, aruchi

- $\quad$ loss of taste is known as Amlapitta. ${ }^{6}$

\section{Need of Study}

Today considering the interest of sound eating regimen and way of life and measures to forestall the way of life issues we should put a light on essential standards which are yet sparkling and similarly relevant in the present situation of ailing condition. In this way, there is a need to express a convention for treating the state of hyperacidity utilizing the rule of Samanya Vishesh Siddhant relying upon the state of the patient, bala, kaal, desh and rutu. All previously mentioned symptoms of Amlapitta can be correlated with the condition of hyperacidity. This rule can be applied to accomplish an adjusted condition of the body and to treat the patients experiencing such conditions.

\section{CONCEPT REVIEW}

\section{Samanya Vishesh Siddhant}

Samanya is always a reason for vruddhi $\sim$ increase in quality and quantity of bhavpadarth (dravya, guna, karma) while Vishesh leads to its hras $\sim$ destruction. ${ }^{7}$ Here sarvada $\sim$ always de-notes in any circumstanc- 
es at any period. Vruddhikaran symbolizes the reason by which vriddhi occurred. ${ }^{8}$ Pravritti ubhayastu implies maintaining a balanced state of dhatus. ${ }^{9}$ Samanya is the cause for the increase and Vishesh is the cause for depletion only when there is commencement. The main motive behind all this is to achieve prakrut original state of dhatus to achieve health. ${ }^{10}$ The entire study of Ayurveda had described as Trisutras hetu $\sim$ causes, linga $\sim$ manifestations and signs and aushad $\sim$ medicines both for sound just as infected one. ${ }^{11}$ While referencing six padarthas, charaka has given first inclination to samanya as information on hetus are likewise samanyamulak indicating similarities. ${ }^{12}$ Samanya is justification for increment or development just when there is not a remotely good excuse for opposing the equivalent. Amla rasa acrid desire for amalaki doesn't expand pitta because of its sheeta virya intensity. Here sheeta virya is a restricting variable for pitta. It ought to be noticed that in samanya samanta $\sim$ closeness in quality (dravya, guna, karma) is the justification behind development or increment and not itself the medication. Cow ghee increments intellectual force and agni, in spite of being gotten from various sources it won't leave its own quality. The quality which brings unconventional contrast ence is known as vishesh. Here vishesh implies the reason for exhaustion contradicting the development. This property is applied in chikitsa. Utilizing aushadhis of inverse nature of vaata knowing the condition of desh, kaal, ritu appeases vaata.

Samaya is ordered by various acharyas in various ways. Acharya charaka has classified into three kinds, in particular, Dravya samanya (devouring the equivalent dravya) like Consuming tissue increments mansa dhatu muscles, Guna samanya (burningthrough a similar nature of dravyas) like burningthrough milk and ghee remedies the consumption condition of shukra dhatu as both have same gunas as that of shukra dhatu and Karma samanya (playing out the demonstration which will in-wrinkle similar properties) Sleeping or relaxation increments kapha in the body while over the top exercise increments vaata because of unsteady nature of vata. ${ }^{13}$ Acharya Bhattar Harish Chandra have referenced sorts of Sa- manya as Atyant samanya (Dravya, guna, karma), Madhyam samanya (any two of Dravya, Guna, Karma), Ekdesh Samanya (any of them). ${ }^{14}$ Kariakvali have referenced with regards to Para samanya and Apara Sa-manya. Also, Vishesh is grouped into Dravya vishesh, Guna vishesh and Karma vishesh by charaka. Utilization of inverse guna dravya to treat the cause, utilization of kulath, baajra, mudaga like heartbeats in heftiness, use oil to treat vitiated condition of vaata as oil have snigdh, ushna and master gunas which are inverse to guna of vaata. Weighty exercise, swimming abatements kapha of the body are these karmas are inverse to stable nature of kapha. $^{14}$

\section{Application in Treatment of Amlapitta}

In the wake of noticing hetus and Samprapti of Amlapitta unmistakably Saman vaayu, dad chak pitta, kledak kapha are straightforwardly engaged with working of Agni. Thus, variety or affront in any of the three doshas influence the course of assimilation and is the causative factor of condition including side effects of Amlapitta. ${ }^{15}$ So for the executives of Amlapitta all doshas are to be thought of. For treatment of any infection preclude the reason. Nidan dad rivarjan is the most significant part of the treatment of any sickness. One should preclude aaharaj (diet), viharaj and mansik (way of life) hetus which are of comparative properties causing the dushti and accordingly succumbing to illness. Forestall ing utilization and practice of hetus will ultimately stop the samanya (comparable) properties and in this manner will forestall the chain of the event of illness. Comparable will apply in treating the state of Amlapitta. One should stop utilization and practice of hetus including Dravya samanya (kulath, broiled grains, drinking over the top water recently made liquor, matured items like curd, idli, dosa, dhokla and so on), Guna samanya dravyas (utilization of ushna hot strength and drava gunatmak food item, amla $\sim$ sour and stuff expands pitta dosh), alongside that rehearsing comparable karmas like exorbitant fasting, concealment of normal urges, eating at an ill-advised time when past isn't as expected processed prompts vitiation of pitta.

${ }^{16}$ Consumption of every one of these hetus goes un- 
der the head of Atyant Samanya causing agni dushti and in this way vitiation of pachak pitta, Saman vaayu and kledak kapha causing Amlapitta. Another supportive of spective of treatment is thinking about the principle of vishesh where utilization of dravyas (having operation posite properties of pitta), gunatah and karmatah vishesh (utilization and rehearsing the different karma) which will diminish the vitiated strength of pitta accordingly adjusting the normal conditions of dosha and dhatus.

\section{RESULT \& DISCUSSION}

The principle of likenesses and dissimilarities normally known as Samanya Vishesh Siddhanta in Ayurveda has a wide degree in the treatment of Amlapitta. This rule will likewise help in anticipation and repeat of sickness. Siddhantas of Ayurvedic science are its foundations. Samanya vishesh Siddhant is one of them which plays a vital guideline in the treatment of dis-ease. Savvy use of Samanya Vishesh standard is a key part in picking the best arrangement of treatment that includes food exercises, way of life change and medicine including shodhan (purifying of the body) and shaman (palliative methodology).

This is the standard of closeness and uniqueness which causes increment and de-wrinkle the property of bhavpadarth individually. Vaidyas can plan different detailing using previously mentioned dravyas as indicated by their need and infection can be not exclusively be dealt with yet, in addition, can be kept from repeat. Thus, in the case of amlapitta dravyas like Guduchi (Tinospora cordifolia), Shatavari (Asparagus racemosus), Patol (Trichosanthes dioica), Bhunimb (Andrographis paniculate), sweet takra buttermilk, Kushmand (Benincasa hispida), Gairik (Red ochre) are used as dravya vishesh in treatment.

Medicines having Tikta $\sim$ bitter, Madhur $\sim$ sweet rasatmak, graahi $\sim$ absorbant, sheet $\sim$ cold potency are considered under guna vishesh and procedure of vaman ayurvedic process of emesis using dravyas like Madanphala (Randia spinosa), Patol (Trichosanthes dioica), Nimbpatra (Azadirecta India), Madhu (Honey) and saindhav, virechan process of purgative healing with dravyas like Haritki (Terminalia chebula), Trivrutta (Operculina terpethum), Draksha (Raisins), Yashtimadhu (Glycyrrhiza glabra) is the vishesh karmas which will expel the vitiated pitta from the body directly. Alongside these couple of ways of life change like strolling after dinners, normal exercise, eating honestly after complete absorption of past food, abstaining from fasting and stress will work on the state of Amlapitta more rapidly and will prevent its repeat.

The expanded interest in sound eating regimens and way of life measures have constrained and favourable to moted to introduce this article to forestall the way of life issues with the assistance of essential rule of Ayurveda. Any infection can be restored effectively when its causative components are precluded and prescriptions and change of inverse appropriate ties are endorsed and burned-through. Consequently, there is a wide degree for applying this Siddhanta in the treatment of different sicknesses. At the point when treatment is given by assessing the condition of doshas pre-sent around then in the body, infection is treated in better ways giving prior help to the patient. Treatment of Amlapitta becomes worked on when we are quite devouring and rehearsing hetus of comparable property and given treatment utilizing drugs, Vihaar and karmas of different properties along these lines accomplishing balance state and alleviation to patient. In this manner, this rule is applicable in the treatment of any non-careful dis-ease.

\section{CONCLUSION}

Siddhantas are the base of Ayurveda. Among this Samanya Vishesh Siddhanta have its exceptional space in the setting of treatment of dis-facilitates. This Principle of Charaka is appropriate to accomplish physical, mental, social, and otherworldly prosperity. By this guideline a medication utilized appropriately will recover the harmony condition of dosha and dhatus which were already dushit (expanded or diminished) and were causing imbalance. Accordingly, utilization of this guideline ends up being a more successful method of treatment including food exercises, meds, and way of life adjustments. 


\section{REFERENCES}

1. Vaidya Yadavji Trikamaji Acharya Editor (Reprint ed.). Sushrut Samhita of Sushruta, Sutrasthan: Chapter 24, Verse 8. Varanasi: Chaukhamba Orientalia, 2014; p. 115.

2. Vaidya Yadavji Trikamaji Acharya Editor (Reprint ed.). Charak Samhita of Charaka, Sutrasthan: Arthedashamuliya Chapter 30, Verse 26. Varanasi: Chaukhamba Orien-talia, 2015; p. 187.

3. Dr. Ambikadatta Shastri Editor (Reprint ed.). Sushruta Samhita of Sushruta, Su-trasthan: Chapter 15, Verse 48. Varanasi: Chaukhamba Orientalia, 2014; p. 84.

4. Available from, http://www.omicsonline.org>India. Last accessed on 17/11/2019.

5. Sri Sudarshan Shastri Editor (Reprint ed.). Madhukosha Sanskrit Commentary on Madhav Nidan of Madhav, Amlapitta Ni-dan, Verse 1. Varanasi: Chaukhamba San-skrit Sansthan, 1992; p. 170.

6. Ibidem 5, Amlapitta Nidan, Verse 1. p. 170.

7. Prof Banwari Lal Gaur, Prof Radheshyam Kalavatiya Editors (Reprint ed.). Ayur-veddipika Sanskrit Commentary on Charaka Samhita of Charaka, Sutrasthan: Dirghajivi-tiya, Chapter 1, Verse 44. Varanasi: Chaukhamba Prakashana, 2011; p. 44.

8. Ibidem 7, Sutrasthan: Dirghajivitiya, Chapter 1, Verse 44 (Tika). p. 44.

9. Ibidem 2, Sutrasthan: Dirghajivitiya, Chapter 1, Verse 44 (Tika). p. 9.

10. Ibidem 7, Sutrasthan: Dirghajivitiya, Chapter 1, Verse 25. p. 33.

11. Ibidem 2, Sutrasthan: Dirghajivitiya, Chapter 1, Verse 45 (Tika). p. 10.

12. Ibidem 2, Sutrasthan: Dirghajivitiya, Chapter 1, Verse 44 (Tika). p. 9.

13. Ibidem 2, Sutrasthan: Dirghajivitiya, Chapter 1, Verse 44 (Tika). p. 9.

14. Ibidem 2, Sutrasthan: Dirghajivitiya, Chapter 1, Verse 45 (Tika). p. 10.

15. Pandit Hemaraja Sharma Editor (Reprint ed.). Kashyapa Samhita of Vruddhajivaka, Chikitsasthan: Amlapittachikitsa Adhyay, Chapter 16, Verse 7-9. Varanasi: Chau-khamba Sanskrit Sansthan, 1988; p. 336.

16. Ibidem 15, Amlapittachikitsa Adhyay, Chapter 16, Verse 3-5. p. 335.

\section{Source of Support: Nil \\ Conflict of Interest: None Declared}

How to cite this URL: Kankre Rameshwari et al: Applied Study Of Samanya Vishesh Siddhanta In Treat-Ment Of Amlapitta (Hyperacidity). International Ayurvedic Medical Journal \{online\} 2021 \{cited October 2021\} Available from: http://www.iamj.in/posts/images/upload/2513_2517.pdf 